\title{
Autorité créative et management des talents dans l'industrie télévisée britannique
}

Le processus d'écriture de Doctor Who (2005-2017)

Authorship and Creative Management in Established British TV. The Writing

Process of Doctor Who (2005-2017)

Autoridad creativa y gestión de talentos en la industria televisual británica. El proceso de escritura de Doctor Who (2005-2017)

\section{Victoire Sessego}

Traducteur : Victoire Sessego

\section{(2) OpenEdition}

\section{Journals}

Édition électronique

URL : http://journals.openedition.org/bssg/417

DOI : $10.4000 /$ bssg. 417

ISSN : 2490-9424

Éditeur

Presses universitaires de Vincennes

Référence électronique

Victoire Sessego, «Autorité créative et management des talents dans l'industrie télévisée

britannique », Biens Symboliques / Symbolic Goods [En ligne], 6 | 2020, mis en ligne le 30 avril 2020,

consulté le 04 mars 2021. URL : http://journals.openedition.org/bssg/417 ; DOI : https://doi.org/

$10.4000 /$ bssg. 417 


\section{Autorité créative et management des talents dans l'industrie télévisée britannique} Le processus d'écriture de Doctor Who (2005-2017)

\section{Authorship and Creative Management in Established British TV}

The Writing Process of Doctor Who (2005-2017)

Victoire Sessego

traduction | translation

Victoire Sessego

\begin{abstract}
La relation entre l'industrie télévisée et la figure de « l'auteur» est difficile à saisir. En effet, il a d'abord été supposé que la télévision n'avait pas d'auteur·e.s, ou plutôt qu'elle en avait un trop grand nombre (Burns \& Thompson 1990), avant que, dans les années 1990, l'industrie télévisée ne se crée un·e auteur·e, le ou la showrunner, scénariste principal·e chargé·e de la production exécutive d'un programme, position construite selon la charte Quality TV. Néanmoins, quand une étude sur les auteur.e.s de l'industrie télévisée est entreprise, elle se résume encore souvent à la recherche du ou de la « véritable » créateur.rice d'un programme (Burns \& Thompson 1990 : chap. 1 et 6 ). Ces difficultés d'appréhension de la notion d'auteur.e dans ce contexte trouvent leur origine dans la représentation de l'œuvre d'art comme produite par un seul individu, quand, particulièrement dans l'industrie télévisée, le processus d'écriture est éminemment collectif (Becker 1974). Pour dépasser cette matrice individualisante, et, in fine, tenter de dépasser la fétichisation de l'auteur·e (Bourdieu 1992 :
\end{abstract}

Authorship in television has been hard to apprehend. Television has been deemed authorless, or rather overly polyauthorial (Burns \& Thompson 1990), before becoming "authored" in the 1990s, with the rise of the showrunner, head writer and executive producer of a show, now seen as its "author." Even when a work on authorship is undertaken, it is merely a search for the show's "real" creator (Burns \& Thompson 1990: chapters 1 and 6). These difficulties stem from an implicit definition of authorship as the production of a work of art by a single individual (common dictionary definition), whereas, in television specifically, the production process is a collective one (Becker 1974). It forces us to redefine authorship to fit the reality. Thus we consider authorship in a broader perspective, as the origin of a written work (the etymological meaning of the word), to be able to rebuild authorship without the (single) creator "fetish" (Bourdieu 1996). Considering the fact that television industries reward authorship through credits, thus naming a "writer," our investigation leads us to reconsider credits as a negotiated recognition of 
231), nous proposons d'explorer la notion plus large d'auteurité ${ }^{1}$, que l'on peut définir comme l'ensemble des éléments ayant contribué à la création d'une œuvre. L'auteurité offre ainsi un cadre plus large et plus souple, pour mieux refléter la réalité de la création, notamment dans l'industrie culturelle. La reconnaissance d'individus comme auteur·e.s, à travers les crédits au générique, nous est ainsi apparue comme une reconnaissance négociée et donc comme un arrangement faisant partie du drame social du travail (Hughes 1984 : 338-348)

Dans cet article, nous nous concentrons sur le processus d'écriture de la série de science-fiction Doctor Who (1963-1989, 2005-) qui, malgré sa longévité et son statut iconique dans la culture britannique, n'a ni créateur officiel ni acteurs présents sur le long terme (le personnage principal, le Docteur, se "régénère " régulièrement, ce qui permet de choisir un nouvel acteur ou actrice) (pour une présentation plus complète de cette série complexe, voir la vidéo ci-après). Depuis 2005, la promotion de la série met en avant ses différents showrunners ${ }^{2}$, nommés par la BBC : Russell T. Davies (2005-2009), Steven Moffat (2009-2017) et à présent Chris Chibnall (2018-), tous des hommes. Ils seraient les auteurs de la série, menant à une construction artificielle de leur auteurité comme exclusive (Cornea 2009). Les épisodes de la série sont en général indépendants les uns des autres, avec la structure standardisée

1. On a traduit ainsi le concept anglais authorship, qui permet de saisir de manière plus large la qualité d'être auteur.e de quelque chose. Nous avons opté pour le suffixe «-ité » pour la traduction, conformément à la règle pour la substantivation d'adjectif mettant l'accent sur le rôle créatif plutôt que la position (unique) d' auteur.e. Nous avons préféré cette traduction à une autre, « auctorialité », afin de garder la proximité phonétique avec la notion d'autorité créative.

2. On le voit notamment à travers leur place centrale dans la narration de la série documentaire Doctor Who Confidential (2005-2013) workers, and therefore as social arrangements, as part of the drama of work (Hughes 1984: 304-310).

This article focuses on the writing process of the long-running and established series Doctor Who (1963-1989, 2005-), a sciencefiction series, which has a unique place in British culture, and has no creator nor long-lasting actors (as its main character, the Doctor, regenerates, which implies the casting of a new actor) (for a more detailed presentation of this complex show, see video below). Authorship, especially that of the showrunner (Russell T. Davies from 2005 to 2009, Steven Moffat, 2009-2017, Chris Chibnall, 2018-), has been used to brand the show since 2005', riding on the newfound role of the writer-producer as "author" with the rise of Quality TV, leading to a "forcefully" constructed authorship (Cornea 2009). Most episodes are stand-alone with a standardized structure that can be summarized as "resolution, linearity and repetition" (Tulloch \& Alvarado 1984: 83-84), which allows for a division of labour in the writing process, and thus double authorship: that of the showrunner (on the overall tone) and that of the writer (on their episode); but it also creates the risk of excessive standardization. The tension between originality and standardization, which is necessary for production reasons, is indeed a core tension in television industries (Pasquier 1995: 19),

1. For instance, they are at the heart of the documentary series Doctor Who Confidential (2005-2013). 
suivante : « résolution [du problème], linéarité [de l'histoire globale], répétition [de la structure dans l'épisode suivant] » (Tulloch \& Alvarado 1984 : 83-84). Ceci facilite la division du travail d'écriture mais induit le risque d'une standardisation excessive. Les tensions entre originalité et standardisation des processus de production sont au cœur de l'industrie télévisuelle (Pasquier 1995 : 19), car celles-ci se situent dans le pôle commercial du champ artistique, tout en luttant pour leur légitimité (Bourdieu 1992). On fait face à une autre contradiction, car un épisode aurait deux auteur.e.s : le showrunner, maître de la tonalité globale de la série, et le ou la scénariste, auteur·e de l'épisode en question.

\section{https://www.youtube.com/watch?v=S8njnNPIx9g}

En utilisant les outils des études sur la production, d'une part, et de la sociologie du travail, d'autre part, l'objectif de cette étude est de cerner le fonctionnement concret du processus d'écriture, qui est dissimulé par l'idéologie de l'auteur unique, que l'on cherche à déconstruire. En effet, dans l'industrie télévisée britannique, le réalisateur ou la réalisatrice sont supposé.e.s se charger de la faisabilité du scénario et de son esthétique visuelle, et non de la narration, particulièrement dans une série de science-fiction comme Doctor Who. Selon les cas, c'est soit le showrunner, soit le ou la scénariste, qui est désigné·e comme auteur·e de l'épisode. Dans notre démarche, nous pourrons en outre nous appuyer sur le scénario, produit matériel du processus d'écriture.

Si Doctor Who, comme les séries télévisées en général, a été largement étudiée sous le prisme de son audience (voir par exemple Tulloch \& Jenkins 1995) et de ses schèmes narratifs (par exemple, Butler 2007), son processus de production a fait l'objet de peu de travaux. Étudier l'organisation du travail créatif permet notamment de dévoiler une créativité sous contraintes, entre as these industries are on the commercial side of the artistic field and battling for legitimacy (Bourdieu 1996).

\section{https://www.youtube.com/watch?v=5j7fouE4f_k}

Thus, I aim to study the writing process and to uncover the reality behind authorship construction, from the perspective of production studies and of the sociology of work. The focus on the writing process stems from the fact that the scriptwriter (or at times the showrunner) is designated as author in British television, more so than the director, who is mainly concerned with the feasibility and visual aesthetic of the script rather than storytelling, in a science fiction show such as Doctor Who. Furthermore, the writing process produces a material object, the script, on which I could rely.

Just like television itself, Doctor Who's narrative (e.g. Butler 2007) and audience (e.g. Tulloch \& Jenkins 1995) have already been extensively studied by communication studies, but its production process little investigated, especially in sociological terms. A focus on the organization of creative work allows me to unveil creativity under pressure, between economic (here costly special effects), 
pressions économiques (dues ici au coût des effets spéciaux) et tensions sur le marché du travail et dans le champ culturel (Pasquier 1995). De plus, cela permet de mesurer les effets de la construction de l'auteurité sur le processus de production et sur le management des créateur-rice.s. En effet, plus que la notion d'auteur, les industries créatives affectionnent la notion de «talent». Se représenter le scénario comme produit par un « talent » n'est ainsi pas sans conséquences sur l'organisation du travail. Nous ne chercherons pas à analyser la véracité de cette notion, car même les travaux approfondis de Pierre-Michel Menger sur ce point restent peu satisfaisants (Menger 2009). De plus, le « talent » semble être un concept particulièrement ambivalent : comme le souligne Manuel Schotté, il peut être instrumentalisé pour justifier les positions sociales, en ignorant d'autres facteurs, notamment sociaux et économiques (Schotté 2012). Nous nous intéresserons uniquement au « management des talents », c'està-dire au développement par les industries créatives d'une forme spécifique de management et d'organisation du travail, informé par une lecture du monde au prisme du talent.

Comment l'auteurité des différents acteurs, leur représentation de cette auteurité et les contraintes de production interviennentelles dans le processus d'écriture de Doctor Who, tout en tenant compte de l'ambition de la série, l'importance de son image et des contraintes économiques qui pèsent sur elle ? Avec quels impacts ? Pour explorer ce questionnement, nous décrirons dans un premier temps le processus d'écriture d'un scénario, avant de nous intéresser aux conflits relatifs à l'attribution de l'auteurité, qui peuvent être appréhendés comme une lutte pour le prestige et la reconnaissance. Nous aborderons enfin les conséquences de ces luttes sur l'organisation du travail, à travers le modèle de management des talents et son impact sur le processus de production labour market and cultural constraints(Pasquier 1995). Furthermore it highlights the construction of authorship and its consequences on management and the production process. Creative industries are keen on reading creative workers' skills through the concept of "talent," "author" falling in that category. This has consequences on the organization of work. I won't really try to state the veracity of the concept of talent, as even Pierre-Michel Menger's analysis remains unsatisfactory (Menger 2016). "Talent" can also be used to justify positions in the field, excluding social factors (Schotté 2012). The focus will instead be on creative management and the organization of work, and how they are affected by talent ideology.

How do authorships, representations of authorship and production constraints impact the writing process of Doctor Who and its actors, considering its actors, considering the show's ambition, economic constraints and branding? I will first describe the scriptwriting process before discussing conflicts of authorship, which can be understood as a battle for prestige and recognition I will finally consider how negociations on authorship reflect the talent management model of the industry and its consequences on the production process. 


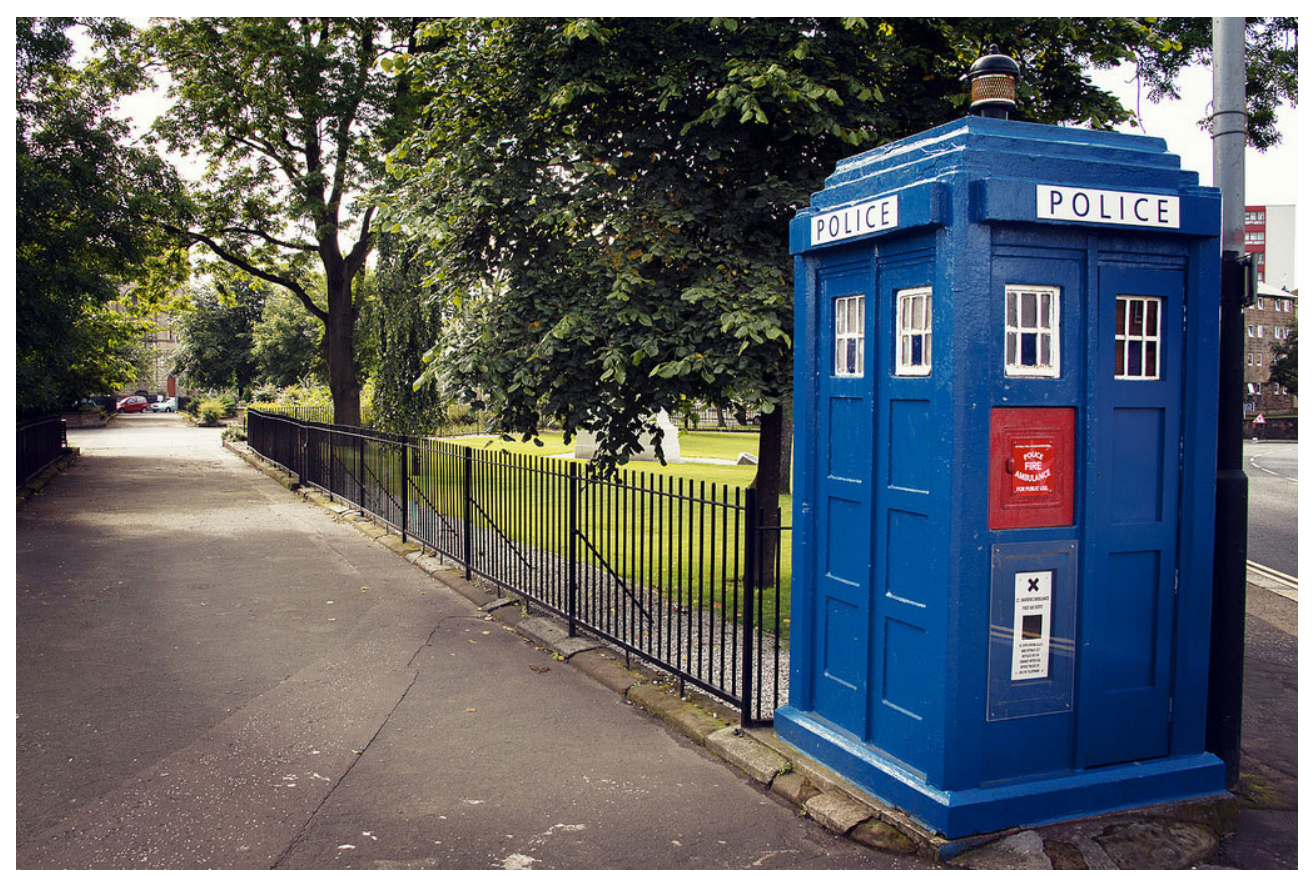

Fig. 1. Doctor Who ? Dans la série, la machine à voyager dans le temps du Docteur, le « Tardis », a l'apparence d'un poste de police / The Doctor's time-travelling machine in the show-the "Tardis"-has the form of a police box @ Dorli Photography. Source : Flickr.

\section{Matériaux utilisés}

Pour pallier la relative inaccessibilité de l'industrie télévisuelle et particulièrement de la BBC (Born 2004), des sources variées ont été utilisées. Des soixante personnes impliquées dans le processus de production de Doctor Who entre 2005 et 2017, nous avons pu en rencontrer cinq pour des entretiens dans le cadre de cette recherche : Robert Shearman (scénariste), Phil Ford (scénariste), Nikki Wilson (script editor et productrice), Derek Ritchie (script editor et producteur) et Mal Young (producteur exécutif et chargé de production
Methodology

Television industries are difficult to access, especially the BBC (Born 2004), therefore a variety of sources were used and my method had to be unconventional. Out of the sixty people involved in the writing process of Doctor Who from 2005 to 2017, five were interviewed as part of the research: Robert Shearman (writer), Phil Ford (writer), Nikki Wilson (script editor and producer) Derek Ritchie (script editor, producer) and Mal Young (executive producer and BBC head of continuing drama). These interviews, based on predefined 
pour les fictions à la BBC). Ces entretiens, s'appuyant sur des questions définies au préalable, étaient centrés sur le processus de production, ainsi que sur les trajectoires professionnelles des enquêté.e.s et leurs relations à l'audience. II leur a été demandé de donner autant de détails et d'exemples possibles, pour ancrer la discussion et éviter des propos trop généraux (Laurens 2007). Cependant, en raison de l'absence des showrunners parmi les enquêté·e·s, d'autres matériaux ont été utilisés, tels que des CV en ligne et des interviews dans les médias, essentiellement dans des médias spécialisés (comme le magazine Den of Geek ou le magazine de la BBC Radio Times) : cent quatre-vingt-quatre en tout, dont quatre-vingt-dix-sept interviews de scénaristes, trente et un de showrunners, quarante-huit de producteurs et huit de script editors. La plupart de ces interviews s'inscrivaient dans un cadre spécifique, celui de la promotion de la série. C'est pourquoi nous nous sommes concentrée sur des questions récurrentes, demandant à l'interviewé·e de raconter une anecdote, en ignorant, par prudence, les considérations d'ordre général. Ce matériau a avant tout été utilisé comme point de comparaison avec les entretiens que nous avons réalisés, afin d'évaluer leur portée générale mais aussi avoir d'autres points de vue sur des événements évoqués en entretien. Parce qu'elles font partie intégrante des campagnes de promotion de la série (et d'autopromotion des interviewé·e·s), les interviews médiatiques présentent des biais supplémentaires : elles peuvent donner une vision enjolivée de la réalité, en effaçant les aspects négatifs, ou exagérer le rôle de la personne interrogée.

Enfin, notre dernière source secondaire est l'ouvrage The Writer's Tale de Russell T. Davies, showrunner de la série entre 2005 et 2010, et Benjamin Cook, journaliste. Ce livre est la transcription d'une correspondance de trois ans entre questions, were centred on the writing process, as well as on professional trajectories and on relationships with the audience. Interviewees were asked to give as much detail and as many examples as possible, to ground the discussion and avoid rehearsed discourses (Laurens 2007). However, as major actors (such as the two showrunners) were not part of the interviews, other material was used. Interviews in the media, mostly from specialized media (e.g. Den of Geek or the BBC's Radio Times) were gathered, one hundred eightyfour were examined in total: ninety-seven interviews with writers, thirty-one with showrunners, forty-eight with producers and eight with script editors, in addition to online resumes. For the most part, these interviews were part of the show's promotion and so were handled with caution, concentrating on topical questions calling for factual anecdotes rather than generalisations. This type of material was used primarily as a point of comparison with my interviews, to establish their generalisation potential as well as to get the perspective of other parties on events brought up in our interviews. However, media interviews came with extra biases: as part of the show's promotion (and of self-promotion), they might give an over-enthusiastic version of reality, by erasing negative aspects as well as emphasizing the interviewee's role. Finally, my last secondary source was The Writer's Tale, a book written by showrunner Russell T. Davies and journalist Benjamin Cook. This book is the transcription of a three-year e-mail correspondence between Davies and the Doctor Who Magazine journalist, focusing on the day-to-day life on the show and especially on the writing process, thus "the writing in motion" (Davies \& Cook 2010: 11, 14). The book contains the same biases as the interviews, the tone is humorous and sometimes emotional and reflects Davies' point of view, so that extra caution was needed to process the subjectivity of 
R. T. Davies et le journaliste du Doctor Who Magazine. Ils y évoquent le travail quotidien du showrunner et en particulier le processus d'écriture, « l'écriture en mouvement » (Davies \& Cook 2010 : 11, 14). L'ouvrage peut comporter des interviews médiatiques biaisées, en raison soit de son ton comique, soit de sa tendance au pathos. En l'analysant avec précaution, cet ouvrage donne cependant un aperçu rare du processus d'écriture au jour le jour, élément manquant dans les entretiens qui ont été réalisés bien après la fin de ce processus. the book. It remains a rare insight on the day-to-day writing process, which was an element missing from the interviews, since they were made long after the writing process was over. 


\begin{tabular}{|c|c|c|c|c|c|c|c|}
\hline Prénom & Nom & $\begin{array}{l}\text { Fonction(s) dans } \\
\text { Doctor Who }\end{array}$ & Saisons & $\begin{array}{c}\text { Années } \\
\text { (environ) }\end{array}$ & $\begin{array}{c}\text { Âge } \\
\text { en } 2020 \\
\end{array}$ & Entretien & Pour plus d'information/de contenu \\
\hline Russell T. & Davies & Showrunner & 1 à 4 & $2002-2010$ & 56 & Non & $\begin{array}{l}\text { https://www.imdb.com/name/nm0203961/bio } \\
\text { https://www.youtube.com/watch?v=dEGJIVxbm-0 }\end{array}$ \\
\hline Steven & Moffat & $\begin{array}{l}\text { Scénariste puis } \\
\text { showrunner }\end{array}$ & $\begin{array}{l}1 \text { à } 4 \text { puis } 5 \\
\text { à } 10\end{array}$ & $\begin{array}{l}2002-2007 \\
2017\end{array}$ & 57 & Non & $\begin{array}{l}\text { https://en.wikipedia.org/wiki/Steven Moffat } \\
\text { https://www.youtube.com/watch?v=iBwBIwGbVaA }\end{array}$ \\
\hline Mal & Young & BBC Head of Drama & 1 & $1997-2004$ & 62 & Oui le 03/04/2017 & https://en.wikipedia.org/wiki/Mal Young \\
\hline Phil & Ford & Scénariste & 4 et 8 & $\begin{array}{l}\text { 2007-2009 } \\
\text { 2013-2014 }\end{array}$ & 59 & $\begin{array}{l}\text { Oui, } \\
\text { le 30/03/2017 }\end{array}$ & $\begin{array}{l}\text { https://en.wikipedia.org/wiki/Phil Ford \%28writer\%29 } \\
\text { https://www.youtube.com/watch?v=JOVFzumqiOY }\end{array}$ \\
\hline Robert & Shearman & Scénariste & 1 & 2003-2005 & 49 & \begin{tabular}{|l|} 
Oui, \\
le 02/03/2017
\end{tabular} & $\begin{array}{l}\text { https://en.wikipedia.org/wiki/Robert Shearman } \\
\text { https://www.youtube.com/watch?v=mu omy WLBo }\end{array}$ \\
\hline Nikki & Wilson & $\begin{array}{l}\text { Productrice } \\
\text { puis productrice } \\
\text { exécutive }\end{array}$ & $\begin{array}{l}\text { 8-10 puis } \\
11-\text { présent }\end{array}$ & 2014-présent & & $\begin{array}{l}\text { Oui, } \\
\text { le 02/05/2017 }\end{array}$ & https://www.youtube.com/watch?v=vmCAXHkLMlg \\
\hline Derek & Ritchie & $\begin{array}{l}\text { Script editor et } \\
\text { ensuite producter }\end{array}$ & 8 et 9 & 2013-2016 & & $\begin{array}{l}\text { Oui, } \\
\text { le 29/03/2017 }\end{array}$ & $\begin{array}{l}\text { https://www.imdb.com/name/nm1161697/ } \\
\text { https://www.bbc.co.uk/programmes/p02ptd3b }\end{array}$ \\
\hline Stephen & Thompson & Scénariste & 6,7 et 8 & 2010-2014 & 51 & Non & https://en.wikipedia.org/wiki/Stephen_Thompson_\%28writer\%29 \\
\hline Phil & Collinson & $\begin{array}{l}\text { Produceur puis } \\
\text { producteur exécutif }\end{array}$ & 1 à 4 & $2002-2010$ & 48 & Non & $\begin{array}{l}\text { https://en.wikipedia.org/wiki/Phil Collinson } \\
\text { https://www.youtube.com/watch?v=mlUTZRRGbu4 }\end{array}$ \\
\hline Robert & Holmes & $\begin{array}{l}\text { Script editor et } \\
\text { scénariste }\end{array}$ & & 1968-1978 & & Non & https://en.wikipedia.org/wiki/Robert Holmes \%28scriptwriter\%29 \\
\hline Terrance & Dicks & $\begin{array}{l}\text { Script editor et } \\
\text { scénariste }\end{array}$ & & 1968-1983 & & Non & $\begin{array}{l}\text { https://en.wikipedia.org/wiki/Terrance Dicks } \\
\text { https://www.youtube.com/watch?v=S3du7WJRN78 }\end{array}$ \\
\hline Richard & Curtis & Scénariste & 5 & 2010 & 62 & Non & $\begin{array}{l}\text { https://en.wikipedia.org/wiki/Richard Curtis } \\
\text { https://www.youtube.com/watch?v=WoglY2inBlg }\end{array}$ \\
\hline Neil & Gailman & Scénariste & 6 et 7 & $2010-2013$ & 58 & Non & $\begin{array}{l}\text { http://neilgaiman.com } \\
\text { https://www.youtube.com/watch?v=wcQTaXwCrNO }\end{array}$ \\
\hline Mike & Bartlett & Scénariste & 10 & 2016 & 38 & Non & https://en.wikipedia.org/wiki/Mike Bartlett \%28playwright\%29 \\
\hline Mark & Gatiss & Scénariste et acteur & $\begin{array}{l}1,2,5,6 \\
8-10\end{array}$ & $2002-2017$ & 52 & Non & $\begin{array}{l}\text { https://en.wikipedia.org/wiki/Mark Gatiss } \\
\text { https://www.youtube.com/watch?v=u4dIP67r2jE }\end{array}$ \\
\hline James & Moran & Scénariste & 4 & 2007-2008 & 47 & Non & $\begin{array}{l}\text { https://www.imdb.com/name/nm1231249/bio?ref }=\mathrm{nm} \text { ov bio sm } \\
\text { https://www.youtube.com/watch?v=fXektQzo-fM }\end{array}$ \\
\hline
\end{tabular}

Tableau 1. Tableau récapitulatif des personnes ayant travaillé pour la série Doctor Who, mentionnées dans cet article 


\begin{tabular}{|c|c|c|c|c|c|c|c|}
\hline Name & Surname & $\begin{array}{l}\text { Function(s) in } \\
\text { Doctor Who }\end{array}$ & $\begin{array}{l}\text { Series } \\
\text { worked on }\end{array}$ & Years (about) & $\begin{array}{l}\text { Age } \\
\text { in } 2020\end{array}$ & $\begin{array}{l}\text { Interviewed in } \\
\text { the research }\end{array}$ & More information/content \\
\hline Russell T. & Davies & Showrunner & 1 to 4 & 2002-2010 & 56 & No & $\begin{array}{l}\text { https://www.imdb.com/name/nm0203961/bio } \\
\text { https://www.youtube.com/watch?v=dEGJIVxbm-0 }\end{array}$ \\
\hline Steven & Moffat & $\begin{array}{l}\text { Writer and then } \\
\text { showrunner }\end{array}$ & 1 to $4 ; 5$ to 10 & $\begin{array}{l}\text { 2002-2007; } \\
2008-2017\end{array}$ & 57 & No & $\begin{array}{l}\text { https://en.wikipedia.org/wiki/Steven Moffat } \\
\text { https://www.youtube.com/watch?v=iBwBlwGbVaA }\end{array}$ \\
\hline Mal & Young & BBC Head of Drama & 1 & $1997-2004$ & 62 & $\begin{array}{l}\text { Yes, on April, 4th } \\
2017\end{array}$ & https://en.wikipedia.org/wiki/Mal Young \\
\hline Phil & Ford & Writer & 4 and 8 & $\begin{array}{l}\text { 2007-2009; } \\
\text { 2013-2014 }\end{array}$ & 59 & $\begin{array}{l}\text { Yes, on March, } \\
\text { 30th } 2017\end{array}$ & $\begin{array}{l}\text { https://en.wikipedia.org/wiki/Phil Ford \%28writer\%29 } \\
\text { https://www.youtube.com/watch?v=JOVFzumqiOY }\end{array}$ \\
\hline Robert & Shearman & Writer & 1 & 2003-2005 & 49 & $\begin{array}{l}\text { Yes, on March, } \\
\text { 2nd } 2017\end{array}$ & $\begin{array}{l}\text { https://en.wikipedia.org/wiki/Robert Shearman } \\
\text { https://www.youtube.com/watch?v=mu omy WLBo }\end{array}$ \\
\hline Nikki & Wilson & $\begin{array}{l}\text { Producer and then } \\
\text { executive producer }\end{array}$ & $\begin{array}{l}\text { 8-10 and then } \\
\text { 11-present }\end{array}$ & 2014-present & & $\begin{array}{l}\text { Yes, on May, 5th } \\
2017\end{array}$ & https://www.youtube.com/watch?v=vmCAXHkLMlg \\
\hline Derek & Ritchie & $\begin{array}{l}\text { Script editor and } \\
\text { then producer }\end{array}$ & 8 and 9 & 2013-2016 & & $\begin{array}{l}\text { Yes, on March, } \\
\text { 29th } 2017\end{array}$ & $\begin{array}{l}\text { https://www.imdb.com/name/nm1161697/ } \\
\text { https://www.bbc.co.uk/programmes/p02ptd3b }\end{array}$ \\
\hline Stephen & Thompson & Writer & 6, 7 and 8 & 2010-2014 & 51 & No & https://en.wikipedia.org/wiki/Stephen Thompson \%28writer\%29 \\
\hline Phil & Collinson & $\begin{array}{l}\text { Producer and then } \\
\text { executive producer }\end{array}$ & 1 to 4 & $2002-2010$ & 48 & No & $\begin{array}{l}\text { https://en.wikipedia.org/wiki/Phil Collinson } \\
\text { https://www.youtube.com/watch?v=mlUTZRRGbu4 }\end{array}$ \\
\hline Robert & Holmes & $\begin{array}{l}\text { Script editor and } \\
\text { writer }\end{array}$ & & 1968-1978 & Dead & No & https://en.wikipedia.org/wiki/Robert Holmes \%28scriptwriter\%29 \\
\hline Terrance & Dicks & $\begin{array}{l}\text { Script editor and } \\
\text { writer }\end{array}$ & & 1968-1983 & & No & $\begin{array}{l}\text { https://en.wikipedia.org/wiki/Terrance Dicks } \\
\text { https://www.youtube.com/watch?v=S3du7WJRN78 }\end{array}$ \\
\hline Richard & Curtis & Writer & 5 & 2010 & 62 & No & $\begin{array}{l}\text { https://en.wikipedia.org/wiki/Richard Curtis } \\
\text { https://www.youtube.com/watch?v=WoglY2inBlg }\end{array}$ \\
\hline Neil & Gailman & Writer & 6 and 7 & $2010-2013$ & 58 & No & $\begin{array}{l}\text { http://neilgaiman.com } \\
\text { https://www.youtube.com/watch?v=wcQTaXWCrNO }\end{array}$ \\
\hline Mike & Bartlett & Writer & 10 & 2016 & 38 & No & https://en.wikipedia.org/wiki/Mike Bartlett \%28playwright\%29 \\
\hline Mark & Gatiss & Writer and actor & $\begin{array}{l}1,2,5,6 \\
8-10\end{array}$ & $2002-2017$ & 52 & No & $\begin{array}{l}\text { https://en.wikipedia.org/wiki/Mark Gatiss } \\
\text { https://www.youtube.com/watch?v=u4dIP67r2jE }\end{array}$ \\
\hline James & Moran & Writer & 4 & $2007-2008$ & 47 & No & $\begin{array}{l}\text { https://www.imdb.com/name/nm1231249/bio?ref }=\mathrm{nm} \text { ov bio sm } \\
\text { https://www.youtube.com/watch?v=fXektQzo-fM }\end{array}$ \\
\hline
\end{tabular}

Table 1. Synthesis of all the persons who had worked on Doctor Who and who are mentioned in this text 


\section{L'écriture : un processus collaboratif}

1.1. Le point de vue du scénariste

Pour explorer le processus d'écriture d'une série comme Doctor Who, il est nécessaire d'en décrire les étapes. Le processus démarre par la commande du scénario. Un scénario couvre un épisode, bien que certains arcs narratifs en couvrent deux. Pour que la commande puisse être passée, la production doit définir quels épisodes seront écrits par le showrunner (qui écrit traditionnellement six des treize ou quatorze épisodes d'une saison, tandis que d'autres scénaristes sont recruté·e.s pour écrire le reste des épisodes). Un épisode prend d'abord la forme d'un résumé, qui est soit fourni au moment de la commande par la production, soit rédigé par le ou la scénariste. La commande se fait à l'occasion d'une réunion avec le showrunner. Le processus est relativement lent, avec plusieurs versions plus détaillées du résumé. Plusieurs versions du scénario se succèdent ensuite, entre trois et cinq, soit plus que la moyenne de l'industrie télévisée états-unienne, mais conformément aux habitudes de la BBC (Born 2004). Le processus prend au total environ six mois, ce qui est bien différent de l'écriture à rythme soutenu de feuilletons télévisés comme Plus belle la vie, où les scénarios, pour une semaine de diffusion doivent être prêts en quatre semaines (Mille 2016). Entre chaque version, le ou la scénariste reçoit des notes d'un ensemble de personnes : le showrunner, les producteur.rice-s exécutif·ve·s, les producteur.rice.s et le ou la script editor. Ces notes, qui portent sur la structure narrative, les personnages, l'intrigue, mais aussi sur la faisabilité du scénario, sont souvent explicitées au cours de réunions. En général il reste ensuite un mois au ou à la scénariste pour réécrire son scénario en prenant en compte ces notes. Cette étape inclut potentiellement des réunions informelles avec le ou la script editor, afin de résoudre des «problèmes " spécifiques. Par exemple, D. Ritchie, alors script editor, se remémore avoir

\section{Writing: A Collaborative Process}

\subsection{The Perspective of the Writer}

In order to explore the writing process of long-running shows, describing its steps is necessary. The writer's work begins when the script is commissioned. A script covers one episode, but a writer can be commissioned for a story that runs through two episodes. Commissioning implies that the production team has defined which episodes will be written by the showrunner himself (six episodes out of thirteen or fourteen episodes per series). An episode starts with an outline, which is included in the commission or elaborated from scratch by the writer. Commissioning officially starts with a meeting with the showrunner. The process unfolds slowly, as the outline goes through different drafts. After the outline comes the script, which also goes through different drafts, usually between three and five, more on average than on American television for example, as is consistent with the BBC's habits (Born 2004). It takes around six months to complete a script, which has little to do with the hurried writing of soap operas such as the French Plus belle la vie, for which a week's worth of episodes needs to be ready in four weeks' time (Mille 2016). Between each draft, the writer receives notes from a variety of persons: the showrunner, executive producers, producers and the script editor. These notes, which comment on the narrative structure, characters and plots, but also on the feasibility of the script, are usually explained during a meeting with some or all of these actors. After taking all this in, the writer then has a month to rewrite his/her script. This step also includes informal meetings with the script editor in order to solve identified "issues." For instance, D. Ritchie recalls spending an afternoon with Stephen Thompson, as the plot of his episode was deemed too complicated and unclear. Stories can evolve quite radically through this process. The episode written by $R$. Shearman 
passé une après-midi avec le scénariste Steven Thompson afin de clarifier son intrigue, jugée trop complexe. Par ce procédé, les intrigues peuvent évoluer de façon assez radicale. Par exemple, à propos de l'épisode qu'il a écrit, $R$. Shearman décrit ainsi la première version de son scénario ${ }^{3}$

« Le personnage dans le rôle du méchant était la femme de notre ploutocrate américain [...]. Elle était à l'étage et torturait [un «Dalek $\left.{ }^{4} »\right][\ldots]$ tout ça pour le faire parler. Quand le Dalek s'échappe, monte les escaliers et la confronte [...] elle demande alors "Est-ce que mon mari parle de moi ?" [...] Elle était supposée exprimer cette émotion simple et déchirante... de solitude. »

Finalement, le personnage devient un ploutocrate misogyne qui garde emprisonné un Dalek dans sa base souterraine. Celui-ci parvient à s'échapper mais, parce qu'il a ingéré de l'ADN humain pour se régénérer, se trouve doté d'émotions : il ne le supporte pas et finit par se suicider. D'un drame éminemment humain, l'épisode a évolué vers une intrigue de science-fiction plus conventionnelle autour d'un extraterrestre, R. Shearman ayant suivi en cela les conseils de R. T. Davies.

Tant que le scénario n'a pas atteint sa version finale, la commande peut être annulée à tout moment. La production a même tendance à commander plus de scénarios qu'il n'y aura d'épisodes : R. Shearman, dont la commande d'un épisode de la saison 5 a été annulée, se rappelle ainsi que dix-huit ou dix-neuf scénarios avaient

3. Sauf mention contraire, toutes les citations proposées et traduites dans cet article proviennent soit d'entretiens menés avec les enquêté e.s, soit de la correspondance électronique poursuivie avec elles et eux.

4. Les Daleks sont les extraterrestres emblématiques de Doctor Who, ils incarnent le mal absolu. illustrates this phenomenon. R. Shearman describes his first draft in the following way2:

"So the lead sort of villain was the wife of our American plutocrat $[. .$.$] she's upstairs and she's torturing [a "Dalek"3]$ $[\ldots]$ all because she wants it to speak. The pay-off to all that is when it gets out, walks up the stairs and finally confronts her $[\ldots]$ and she would say 'Just, does my husband ever mentions me?' [...] it was supposed to be this achingly simple emotion... of loneliness."

In the end, his episode was about a misogynistic billionaire keeping a Dalek in his underground base. The Dalek, once regenerated by human touch, escaped but committed suicide because it had been given emotions. The episode thus went from a human drama to a more conventional science-fiction plot, revolving around an alien, R. Shearman having followed R. T. Davies' instructions.

Before the script has reached its final draft, the commission can fall through at any time. The show even relies on over-commissioning. R. Shearman, whose commission fell through in series 5 , recalls that eighteen or nineteen episodes were originally commissioned, with only thirteen episodes planned to air. Once approved by the executive producers, the script is sent to the director, who starts prepping for the tone meeting. This meeting aims at discussing

2. Unless mentioned otherwise, every quotation in the article is extracted from interviews or subsequent emails.

3. Daleks are aliens, they are the iconic villains in the show 
initialement été commandés, pour seulement treize épisodes. Une fois validé par la production exécutive, le scénario est envoyé au réalisateur ou à la réalisatrice, qui commence sa préparation pour le tone meeting (littéralement, "réunion sur la tonalité »). Cette réunion concerne essentiellement la mise en images concrète du scénario. Le réalisateur ou la réalisatrice, ainsi que le ou la scénariste, peuvent exprimer leur point de vue, bien que la production exécutive ait le dernier mot, comme l'a décrit $\mathrm{N}$. Wilson. Vient ensuite la lecture du scénario par les comédien·ne·s. Elle a lieu quelques jours avant le début du tournage, et revêt une forte valeur symbolique : les comédien-ne·s interprètent leur texte pour la première fois, en présence de l'ensemble de la production et de quelques privilégié $\cdot e \cdot s$ (des hauts fonctionnaire de la BBC par exemple). Après cela, il n'y aura plus que des « ajustements de dernière minute " (pour reprendre les mots de Wilson), contrairement au tone meeting, à la suite duquel les changements sont parfois significatifs. Après cette étape de lecture, le travail du ou de la scénariste est terminé. Mais il ou elle se rend en général sur le lieu du tournage pour une journée, principalement pour participer à la promotion ultérieure de leur épisode (voir par exemple cette vidéo promotionnelle). Cependant, cette journée sur le plateau met souvent les scénaristes mal à l'aise, car ils ou elles se sentent comme « la cinquième roue du carrosse » (selon

l'expression utilisée par P. Ford et R. Shearman).

Ainsi la réécriture du scénario, à l'aide des notes reçues, constituet-elle une part centrale du processus d'écriture. Pourtant, ce terme de «notes" est vague. C'est pourquoi nous devons à présent nous pencher sur cette notion, qui place le scénario au cœur du an episode's "tone." It mainly deals with the coming to life of the script in concrete terms. Both director and writer are present, which means that the writer has the possibility to speak their mind, even though executive producers have the final word, as described by $\mathrm{N}$. Wilson. Then comes the read-through: the event, which takes place a few days before shooting begins, has a more symbolic value. Actors perform the script for the first time, in the presence of the production crew as well as other privileged players, such as BBC controllers. After the tone meeting, substantial changes can still be made, whereas only "last-minute amends" can be made after a read-through, according to $\mathrm{N}$. Wilson. After the readthrough, the writer's task is over, even if they usually come on set for one day, mainly for publicity reasons (see for instance this promotional video). However, these visits also often make writers uneasy, because they feel like a "third wheel" (expression used by P. Ford and R. Shearman).

Thus, the central part of the writing process is the rewrites made by the writer, after receiving notes on their last draft. However, the term "notes" is quite vague, which is why we have to analyse it further, to show how they put the script in the centre. 


\subsection{Le scénario comme moyen de communication :} la multiplication des notes

Le scénario peut être considéré comme un objet matériel à l'intersection de tous les domaines du processus de production : un medium favorisant la collaboration et qui vient s'ajouter aux interactions sociales, en structurant notamment le calendrier de travail des différents acteurs (Davies \& McKenzie 2004). Le scénario doit avant tout permettre de fournir des informations. Ainsi, les notes pointent en général des éléments ayant besoin d'être clarifiés, afin que toutes les personnes qui l'utilisent puissent y trouver les éléments nécessaires pour faire leur travail. Écrire devient donc un processus d'explication (Mille 2013). Les notes, qui sont faites directement sur le scénario ou sur un document joint, sont de trois formes : les notes relatives à l'histoire, celles relatives à la production et ce que nous appellerons les notes de

mise en scène.

Les notes relatives à l'histoire proviennent essentiellement du showrunner. Elles concernent les personnages, les lieux et l'intrigue, en suggérant des changements ou des éléments à ajouter. Pour l'épisode de P. Ford qui se déroule sur Mars, le showrunner $R$. T. Davies suggère dans ses notes de réduire la taille de la base spatiale (qu'il décide de nommer la «base Bowie ») où se passe l'action et de la rendre plus « primitive »; il décide également de rendre historiques les événements qui s'y déroulent pour que le Docteur, qui est un "Seigneur du Temps ", les connaisse à l'avance (Davies \& Cook 2010 : 426-428). Cependant, ces notes peuvent aussi provenir de la production exécutive ou de la production. Par exemple, une scène d'un épisode intitulé «The Caretaker " ("Le concierge »), dans laquelle le Docteur et une élève se lient d'amitié, est attribuée à $\mathrm{N}$. Wilson. Les notes relatives à l'histoire constituent ainsi une manière pour les producteurs et les productrices d'interagir avec le scénario, afin d'être à même de

\subsection{The Script as a Means of Communication: the Proliferation of Notes}

The script can be described as a temporal boundary object in the production process, a medium of collaboration that supplements social interactions and structures work timelines (Davies \& McKenzie 2004). Just as the script provides information, notes usually require the writer to clarify their script, so that all workers can take what they need from it, depending on their tasks. Writing becomes a process of explanation (Mille 2013). The notes, all directly made on or adjoined to the script, are of three types: storybased notes, production notes and those I will call direction notes.

Usually, the showrunner provides most of the story-based notes, commenting on characters, locations, plots and suggesting additions or changes. If we look at R. T. Davies' notes on P. Ford's first episode, taking place on Mars, R. T. Davies suggests making the base more "primitive" and smaller, calling it "Bowie base" or making the events "historical," so that the Doctor, being a "Time Lord", is aware of them (Davies \& Cook 2010: 426-428). However, executive producers and producers get to write story-based notes as well. For example, a scene in "The Caretaker," in which the Doctor and a pupil are bonding, is attributed to N. Wilson. Storybased notes are mainly a way for producers to make sure they engage with the story, since they are the one making decisions on the parts of the script to be cut in case of delays in production. Though valued, story-based notes are not required of producers. Production notes, however, are at the heart of executive producers' and producers' job. These notes communicate to the writer, via the 
prendre des décisions plus loin dans le processus de production (notamment sur les coupures à réaliser en cas de retard). Bien que ces notes soient considérées comme importantes par l'équipe, la

production n'est en principe pas obligée d'en fournir.

Les notes relatives à la production, en revanche, sont au cœur du travail de la production exécutive. Elles servent à communiquer au ou à la scénariste, à travers le scénario, les contraintes de production. Les producteurs et les productrices font en effet le lien entre toutes les étapes de production, en gérant notamment ses aspects financiers. Par exemple, Phil Collinson, producteur exécutif, suggère dans l'une de ses notes de recourir à une zone industrielle comme lieu de tournage d'un épisode (Davies \& Cook 2010 : 143-144), tandis que N. Wilson mentionne qu'elle avait suggéré l'utilisation des angles de caméra pour minimiser le coût des effets spéciaux. Ces notes demandent également au ou à la scénariste de décrire plus précisément certains monstres ou accessoires qui vont figurer dans l'épisode, afin de permettre leur mise en production le plus rapidement possible (D. Ritchie). Écriture et production concrète sont ainsi étroitement mêlées, le scénariste doit s'adapter aux contraintes matérielles et économiques de la production. Par exemple, R. Shearman dut choisir entre plusieurs scènes de bataille, tandis que R. T. Davies, showrunner, dut réécrire, dans l'épisode «Partners in Crime» («Complices»), une scène, pourtant cruciale à la narration, car elle ne pouvait pas être filmée sans enfreindre les règles de sécurité et d'hygiène (Davies \& Cook 2010 : 224). Les scénaristes peuvent aussi s'immiscer dans la production elle-même, en glissant dans leur scénario des notes de réalisation, communiquant ainsi avec la production et la réalisation. Ces notes peuvent être définies comme des parties du scénario qui ne sont pas essentielles mais qui apportent des informations supplémentaires. R. T. Davies affirme ainsi que son style et sa mise en page sont une façon de communiquer au script, production constraints. Producers are indeed the tangible link between all the steps of production, managing the financial side. For example, executive producer Phil Collinson suggested using an industrial area as location for one of R. T. Davies' episodes (Davies \& Cook 2010: 143-144), while N. Wilson mentioned how camera angles could be used to reduce special-effects costs. Production notes can also ask for precisions on creatures or props, since building has to start as soon as possible, as highlighted by D. Ritchie. Writing and production are therefore intertwined and writers have to adapt their script to economic challenges. For instance, R. Shearman was asked to choose between several battle scenes, while R. T. Davies had to rewrite a narratively crucial scene in Partners in crime, because it could not be shot without breaching Health and Safety regulations (Davies \& Cook 2010: 224). Cutting special-effects costs is also among R. T. Davies' greatest worries when writing, showing how much production constraints weigh on the writing process. Yet, writers can also write direction notes, communicating with producers and director, via the script. Direction notes are elements of the script, that are not entirely necessary but provide extra information. R. T. Davies discusses how his style and layout are a way to communicate his vision of the script to the director, using capital letters, putting concise descriptions of each character, writing "Pause" on a line of its own, specifying camera angles or special effects (Davies \& Cook 2010:110-119; 646). The stakes for the writer are high. An omission might lead to missing the writer's intent. For instance, R. T. Davies mourns the effect he intended for a scene in the episode "Partners in Crime": it was not carried out because he forgot to specify the two characters' positions (Davies \& Cook 2010: 245). 
réalisateur ou à la réalisatrice sa vision du scénario : passages en majuscule, description concise de chaque personnage, mention des « Pauses » sur une ligne à part, indication du cadrage caméra ou du type d'effets spéciaux (Davies \& Cook 2010 : 110-119; 646). Les enjeux sont importants pour le ou la scénariste. Le risque est en effet de passer à côté de certains effets prévus : dans " Partners in Crime », par exemple, Davies a dû se résoudre à ne pas voir retranscrit à l'écran l'un des effets qu'il avait imaginés, parce qu'il n'avait pas précisé la position de deux personnages (Davies \&

Cook $2010: 245)$.

Ainsi, en se concentrant sur le scénario, on a évoqué toutes les personnes qui participent à sa création, à l'exception d'une seule : le ou la script editor. Les script editors sont rarement spontanément mentionné·e·s par les scénaristes dans les entretiens et les interviews, alors qu'on peut les considérer comme comme la main invisible du processus d'écriture ${ }^{5}$

\subsection{Le ou la script editor, coordinateur-rice du processus de production}

Les script editors (un·e par épisode, en général deux par saison, qui travaillent ensemble pour assurer une forme de continuité) font le lien entre les scénaristes et le reste de l'équipe de production. Ce sont elles et eux qui envoient au ou à la scénariste les notes de toute l'équipe sur chaque version du scénario, en rédigeant une introduction avec un résumé des points principaux (voir pour un exemple Davies \& Cook 2010 : 139-140). Ils et elles jouent le rôle d'assistant.e.s du processus de production, en planifiant les réunions d'écriture et les calendriers de production, mais aussi en étant à la disposition des scénaristes en cas de besoin. Ils et elles annotent également le scénario, mais sous un angle plus

5. Les script editors sont d'ailleurs les seul·e.s à qui l'on demande en quoi consiste leur travail en interviews.
Through the script, we have thus mentioned all actors taking part in the script but one, often not mentioned, even by writers in interviews, unless asked about them: the script editor, the invisible hand of the writing process ${ }^{4}$.

\subsection{The Script Editor, Coordinator of the Writing Process}

Script editors (one per episode, usually two per series, working together for continuity) liaise between the writers and the rest of the production team. They are the ones who, for each draft, send the notes from the whole creative team to the writer, with an introduction summarizing their main topics (for an example, see Davies \& Cook 2010: 139-140). They play the role of assistants of the writing process, scheduling script meetings and deadlines (and keeping the rest of the team to it), as well as being at the writers' disposal if they need someone to discuss their script with. They also get to write notes, though of a technical nature, as they have to ensure that the script fits into the production format, especially in

4. They are indeed the only ones asked about their concrete jobs in interviews. 
technique, car ils et elles doivent s'assurer que les scénaristes respectent le format prévu, en termes de longueur ou de politique éditoriale ${ }^{6}$. En résumé, les script editors, pour qui il peut s'agir d'un premier poste, prennent en charge le « sale boulot » du processus d'écriture (Hughes 1984 : 338-348). Ils et elles s'assurent en effet que les standards de production et les échéances sont respectés, quand le travail créatif rejette en partie les normes et les procédures industrielles (Hesmondhalgh \& Baker 2011: 84). R. T. Davies refuse, par exemple, que les analyses de son ouvrage puissent servir de norme pour l'écriture de scénario. Les script editors peuvent être considérée.e.s comme les seuls personnels dits below the line dans le processus d'écriture, c'est-à-dire sous le seuil de ce que l'on reconnaît comme travail créatif dans un film (Banks 2009). Pourtant, tout comme les infirmier ère-s, qui effectuent le « sale boulot » hospitalier, insistent sur leur rôle dans le processus de guérison (Hughes 1984 : 338-348), les script editors mettent l'accent sur l'aspect créatif de leur travail, en tant qu'assistant·e.s des scénaristes (comme l'illustre cette anecdote de D. Ritchie, voir plus haut §6). En outre, parce qu'ils et elles sont chargé.e.s de synthétiser des notes souvent contradictoires, tout en restant diplomates (Davies \& Cook $2010: 140-141$ ), ils et elles assument également des fonctions « féminines » de réconfort et de communication. Cet aspect genré de la position est confirmé par la part élevée de femmes dans cette activité ( $43 \%$, comparé à $14 \%$ pour les scénaristes)

Le statut de script editor a évolué avec le modèle Quality TV, qui a transféré la plupart de ces tâches créatives aux scénaristes et au showrunner(Robinson 2010). En tant que scénariste principal, celuici a la possibilité de revendiquer le statut d'auteur, tandis que le ou

6. II s'agit de vérifier la mise en forme du script, mais aussi le respect de la politique éditoriale de la BBC pour les contenus pour enfants (violence, langage, etc.). terms of length, as well as editorial policy ${ }^{5}$. To sum up, script editors, performing an entry-level job, do the "dirty work" of script writing (Hughes 1984: 338-348). They indeed make sure that production standards and deadlines are respected, when the creative work partly rejects norms and industrial procedures (Hesmondhalgh \& Baker 2011: 84), as shown by R. T. Davies, who refuses to be normative in his book. Script editors can be considered as the only "below-the-line" workers in the writing process, i.e. agents whose work is not recognized as creative (Banks 2009). Yet, just as nurses who, while taking care of the "dirty work," stress their role in the healing process (Hughes 1984: 338-348), script editors put an emphasis on the creative side of their job, assisting writers at every step (as shown previously -see § 9- by D. Ritchie's anecdote on the troubleshooting of an entangled script). Moreover, as they summarise conflicting notes to writers in an agreeable way (Davies \& Cook 2010: 140-141), they also assume "feminine" functions of reassurance and communication, which is somewhat confirmed by the gender ratio in this activity ( $43 \%$ of women, compared to $14 \%$ for writers).

The status of script editors changed with Quality TV, which transferred most of their creative power to writers and showrunners (Robinson 2010): the showrunner, as head writer, is able to claim the authorship status while the script editor is left with only his/ her supervising role. This change of status illustrates how creative

5. i.e. the lay-out of the script, but also the respect of the BBC's editorial policy concerning contents aimed at children (violence, language, etc.). 
la script editor n'a gardé qu'un rôle de supervision. Ce changement de statut illustre bien le fait que la reconnaissance de l'auteurité et sa répartition dépendent de rapports de force. Par exemple, on reconnaît encore aujourd'hui l'importance de l'apport créatif de Robert Holmes et Terrance Dicks, qui ont travaillé comme script editors pour la série classique Doctor Who (1963-1989), tandis que les script editors de la série contemporaine ne sont généralement pas mentionnéee-s par les scénaristes lors des entretiens et interviews. Avant la montée en puissance du showrunner, les script editors étaient les premier.e.s à lire le scénario à chaque étape et à l'annoter ; ils et elles suggéraient également des idées pour de nouveaux épisodes. Ces tâches sont à présent effectuées par le showrunner et la production exécutive. Dans la configuration actuelle, les tâches techniques et organisationnelles occupent la majorité du temps des script editors. Cela explique pourquoi ils et elles ne figurent pas dans la séquence d'ouverture, et ne sont cité·e·s qu'au générique de fin, avec l'équipe technique.

En décrivant le processus d'écriture et celles et ceux qui y contribuent, nous avons pu mettre en évidence son aspect collectif, souvent dissimulé. Cependant, toutes les personnes impliquées n'ont ni la même influence créative ni la même reconnaissance, ce qui nous invite à explorer l'auteurité dans sa diversité tout au long

du processus de production.

\section{Négociations d'auteurité : un exercice d'équilibriste entre reconnaissance individuelle et essence collective du processus d'écriture}

\subsection{Formes et intensités de l'auteurité}

Ainsi que nous l'avons montré dans l'analyse du processus d'écriture, les scénaristes partagent certaines formes de l'auteurité avec le reste de l'équipe créative. Les scénaristes et le showrunner recognition comes down to power relations. For instance, Robert Holmes and Terrance Dicks are recognized for their years in classic Doctor Who (1963-1989) as script editors and writers, whereas now script editors tend to be left out of the narrative by writers in interviews. In terms of responsibilities, script editors, before the rise of the showrunner, were the first to lay eyes on a new draft; they used to make story-based notes and suggest episode ideas in the commissioning process: these tasks are now taken up by the showrunner and executive producers. In the current setting, the technical and organisational tasks take up most of the script editors time. Consequently, they are the only ones who, despite being involved in the writing process, are not part of the title sequence, and are instead among the technical staff in credits.

Describing the writing process and its actors has allowed us to uncover its mostly hidden collective aspect. However, all the people involved do not have the same creative influence of recognition, which prompts us to investigate authorships along the production process.

\section{Authorship Negotiations: Balancing Individual Recognition and the Collective Nature of the Writing \\ Process}

\subsection{Levels and Forms of Authorship}

Following our account of the writing process, writers share forms of authorship with the whole creative team. Writers and showrunners actually write ideas in their script, while producers can suggest 
sont celles et ceux qui inscrivent directement leurs idées dans le scénario, tandis que les producteur.rice-s ne peuvent que suggérer des idées, qui seront ensuite incorporées dans le scénario par le ou la scénariste. Aux producteur.rice-s exécutif·ve-s revient enfin le pouvoir de décision. Bien que le travail des producteur.rice-s et des script editors soit souvent décrit comme de la "résolution de problèmes » (N. Wilson), leurs idées, formulées sous forme de solutions potentielles, ne leur donnent pas droit au titre d'auteur.e dans le générique. De plus, les scénaristes peuvent remettre en cause (comme l'a souligné P. Ford en entretien), voire ignorer complètement des notes (Davies \& Cook 2010 : 141), du moment que la version suivante de leur scénario est jugée satisfaisante. Ainsi, les scénaristes apprennent au cours de leur carrière à reconquérir une partie de l'auteurité et de leur autonomie en choisissant quelles notes (ne pas) prendre en compte. Pourtant, en étudiant le processus d'écriture, on ne peut pas ignorer le contrôle créatif exercé par le showrunner, de manière officielle à travers ses notes ou son pouvoir de décision, mais également de manière plus informelle, à travers le processus de réécriture et la culture du

secret.

\subsection{Exercer le contrôle en tant que showrunner : culture du}

\section{secret et réécritures}

La BBC, comme les industries créatives en général, est une organisation qui cultive le secret, indispensable à l'effet de surprise narratif. En tant qu'organisation publique, la BBC est également scrutée et critiquée par la presse, si bien qu'elle contrôle autant que possible les informations à son sujet qui sont rendues publiques. Dans Doctor Who, le showrunner et la production exécutive sont responsables de la gestion des "fuites », ce qui fait entrer la culture du secret dans l'organisation même du travail. Ainsi, des changements majeurs dans la production ne sont révélés que très tardivement, même à l'équipe travaillant sur la série. Par exemple, ideas that are then incorporated into the script by the writer, and executive producers hold decision-making power. The producers' and script-editors' jobs are often described as "troubleshooting" (N. Wilson). However, their ideas, expressed as potential solutions, don't give them the right to be credited as such. Writers can contest (as highlighted by P. Ford) or refuse notes (Davies \& Cook 2010: 141), as long as their next draft is deemed good enough. They thus learn throughout their career how to take back some of their authorship and regain autonomy, choosing which notes they (do not) take into account. However, studying the writing process, one cannot help but notice the creative control held by the showrunner, through official means such as notes and decision-making, as well as more informally.

\subsection{Achieving Control as a Showrunner: Secrecy and Rewrites}

The BBC, like creative industries in general, is a secretive organization, since it relies on the element of surprise. As a publiclyfunded institution, the BBC also tends to be harshly criticized by the press and thus aims to control which pieces of information go public. The showrunner and executive producers are responsible for managing leaks, introducing secrecy within the organization of the show itself. They hide major production changes, even to people working on the show, such as the 2009 break in schedule, which has been planned since 2006 but was leaked, unannounced, in late 2007 (Davies \& Cook 2010:213). What is kept secret mostly 
l'arrêt de la production en 2009, qui était prévu depuis 2006, a été rendu public à la fin de l'année 2007 , sans avoir été préalablement communiqué au personnel (Davies \& Cook 2010 : 213). En général, les éléments gardés secrets concernent cependant plutôt le contenu des scénarios. De plus, il n'existe ni « bible » pour fixer personnages et arcs narratifs (Pasquier 1999), ni « tableau feuilletonnant " (comme dans Plus belle la vie, Mille 2013 : 177). C'est ainsi que même des personnages centraux peuvent rester largement indéterminés. Par exemple, le $12^{\mathrm{e}}$ Docteur fut seulement décrit de manière vague à $P$. Ford lors de la commande. Le showrunner devient de cette façon le détenteur ultime de l'identité du personnage, ce qui consolide son autorité. Cet effet est encore renforcé par le management individualisé des scénaristes, qui sont maintenu·e.s à l'écart les un·e.s des autres, comme le décrit $\mathrm{R}$. Shearman. La conséquence principale de cette culture du secret est d'obliger le showrunner à une réécriture finale de tous les épisodes du scénario, après la validation de la dernière version du scénariste, afin d'unifier la tonalité et la narration et de rendre cohérents les personnages. Selon P. Ford, le « vernis » (polish) du showrunner est une pratique courante dans l'industrie télévisuelle britannique. Pourtant, elle ne faisait pas partie de l'organisation de départ de la série. R. T. Davies a commencé à « vernir » la saison 1 , avec l'épisode «The Unquiet Dead ( « Des morts inassouvis »), afin d'attirer l'acteur Simon Callow comme guest star. II présente cela comme une amélioration du scénario, par ajout d'éléments, pour « mettre en valeur une réplique dont le scénariste n'a pas réalisé le potentiel » (Davies \& Cook 2010 : 150), pour standardiser le ton à travers la saison, tout en restant « fidèle " au ou à la scénariste. Pourtant, Davies lui-même qualifie ce « vernis » de " réécriture ", ou de « (ré)écriture » dans la mesure où elle peut, selon lui, concerner jusqu'à « presque $100 \%$ d'un scénario » (Davies \& Cook 2010 : 173-176 ; 150). S'il est courant de réécrire plus ou moins légèrement dans la télévision britannique, la marge de concerns characters and overall story-arcs. There are no bible of characters and arcs (Pasquier 1999), no synthetic table of timelines (as in Plus belle la vie, Mille 2013: 177) in existence. Consequently, central characters can remain undetermined. For instance, the 12 th Doctor was only described in vague indications to P. Ford. The showrunner then becomes the ultimate holder of the character's identity, a fact that strengthens his authority. It is reinforced by the individual management of writers, who are kept apart, as stated by R. Shearman. The main result of this secrecy is to make it necessary for the showrunner to rewrite scripts when they have reached their last draft, as unified tone, story and character identities cannot be achieved otherwise. According to P. Ford, the showrunner's "polish" is a common practice in the television industry. However, it was not part of the original organization of the show. R. T. Davies started "polishing" in series 1 for "The Unquiet Dead," in order to attract Simon Callow as a guest-star. He presented it as improving the script, adding elements "enhancing a line that the original writer hasn't realized is good" (Davies \& Cook 2010:150), standardizing the tone across episodes, while remaining "faithful" to the writer. Yet "polishing" is often referred to as "rewriting," or even as "(re) writ[ing]" by R. T. Davies, covering up to "almost 100 per cent of a script" (Davies \& Cook 2010: 173-176, 150). If a certain amount of rewriting is common in British television, the grasp it gives to the showrunner in Doctor Who, thanks to secrecy, is significantly greater: it had to be explained to $\mathrm{S}$. Moffat, an experienced showrunner, when he replaced R. T. Davies (Davies \& Cook 2010: 297). 
manœuvre qu'elle donne au showrunner dans Doctor Who est considérable, d'autant plus en raison de cette prééminence de la culture du secret : c'est la seule chose qui dut être expliquée à Steven Moffat, qui était pourtant déjà un showrunner expérimenté quand il a remplacé R. T. Davies en 2009 (Davies \& Cook 2010 :

297).

Le seul exemple de réécriture en notre possession a été reproduit dans The Writer's Tale (Davies \& Cook 2010 : 173-176). Il concerne l'épisode «The Fires of Pompeii » («La chute de Pompéi »), qui se déroule à Pompéi au moment de la célèbre éruption. On constate que les changements principaux concernent d'abord les dialogues ; outre l'ajout de nouveaux personnages (les oracles), l'intrigue est restée la même tandis que des répliques sont ajoutées, déplacées ou supprimées. Ce procédé est cohérent avec la description de la pratique du vernis par P. Ford, scénariste, comme « mise au point des dialogues ". Dans cette réécriture, on peut également voir que R. T. Davies développe la personnalité d'un personnage secondaire, en lui donnant un rôle plus important. La réécriture peut aussi mener à des changements plus fondamentaux dans le scénario, particulièrement lorsqu'il s'agit du Docteur, personnage dont la définition et l'évolution semblent être réservées au showrunner. Lorsqu'il a réécrit l'épisode de P. Ford, "Waters of Mars » («La conquête de Mars »), R. T. Davies a ainsi pris en charge l'écriture de la réaction inhabituelle du Docteur. Cela montre comment l'étendue théorique de l'auteurité du scénariste est remise en question par le statut du showrunner selon les critères de la Quality TV.

Les scénaristes, en particulier les moins expérimenté·e·s, apparaissent donc comme des intermédiaires dans le processus de production, à qui l'on délègue une partie du travail du showrunner. Ainsi, R. T. Davies délègue l'épisode «The Fires of Pompeii »
The only example of a before/after re-write in our possession is reproduced in the Writer's Tale (Davies \& Cook 2010: 173-176): it is a rewrite of "Fires of Pompeii." The main changes, apart from the addition of new characters, the soothsayers, can be found in the dialogue, the plot staying the same while the lines' order changes and others are added,, consistent with P. Ford's description of the polish as "tweaks of dialogue." Yet R. T. Davies also develops a secondary character's personality, when he does not alter the Doctor's behaviour entirely (as in "The Waters of Mars," where the Doctor is in an unusual situation). This illustrates how the writer's theoretical authorship is contested by the showrunner's role in Quality TV.

Thus, we can consider the writer as a middle man in the writing process, to whom some of the showrunner's workload is delegated, particularly for writers with less prestige. R. T. Davies clearly delegates the "Fires of Pompeii" episode to J. Moran, new to the 
(«Les flammes de Pompéi ») à James Moran, nouveau-venu dans l'industrie, afin de travailler directement sur un scénario complet et « ré-écrire intégralement » l'épisode après cela (Davies \& Cook 2010 : 97). Les scénaristes produisent ainsi une intrigue cohérente et une première version du scénario, base structurée à partie de laquelle le showrunner peut travailler efficacement. Cependant, même si leur contribution est réécrite, la plupart des scénaristes sont crédité·e·s au générique comme auteur·e·s, comme cela est courant dans l'industrie télévisée. Mais comment l'attribution des crédits est-elle négociée entre scénaristes et showrunners? Autrement dit : comment l'auteurité publiquement reconnue estelle déterminée?

\subsection{Les crédits dans Doctor Who : la pratique du " vernis "} donne-t-elle droit à des crédits ?

Comme nous l'avons vu précédemment, l'auteurité exclusive ou même dominante sur un scénario ne peut être attribuée ni au ou à la scénariste ni au showrunner, si bien que les crédits sont le résultat d'une politique de reconnaissance des scénaristes. La rémunération et les droits d'auteur auraient pu faire partie de cette équation. Cependant, en matière de droits d'auteur et de rémunérations, autres indices d'auteurité, les régulations sont établies en fonction d'accords entre la BBC et la Writer's Guild, syndicat des scénaristes. Les scénaristes étant indépendant·e·s, ils et elles sont rémunéré·e·s à l'épisode selon sa durée à l'écran (avec des commissions supplémentaires si les épisodes sont diffusés sur d'autres chaînes). D'une part, le showrunner dispose d'un contrat qui attribue les droits de toutes ses créations relatives à Doctor Who à la BBC. D'autre part, les autres scénaristes, indépendant.e.s, obtiennent en théorie des droits pour des « personnages originaux " (c'est-à-dire les personnages qui n'étaient pas dans le résumé original) qui sont, de fait, extrêmement rares. industry, to accelerate the process, planning to "re-write him heavily" (Davies \& Cook 2010: 97). Writers are given the task of putting up a coherent plot and writing the first full version of the script, as a structured base from which the showrunner can efficiently work. Nevertheless, most writers are credited, as is standard in the industry, with full credits. How is one's presence in the credits negotiated between writers and showrunners, and how does it change publicly recognized authorship?

\subsection{Credit Policy on Doctor Who: Does "Polishing" Give} Rights to Credits?

As seen previously, it is hard to attribute full or even dominant authorship either to the writer or to the showrunner, so that credits are a policy linked to rewarding and attracting writers. Pay and rights might also have been part of this equation. However, rights, as well as fees, are highly regulated at industry level, through agreements between the BBC and the Writers' Guild, the writer's union (Writers being freelancers, they are paid per episode based on the duration in minutes of an episode (with extra broadcasting fees for broadcast on other channels). On the one hand, the showrunner's contract with the BBC is a hire-contract, which means that all his creations during his employment are property of the BBC. On the other hand, freelance writers theoretically get rights for "original characters," but the strict definition of the term "original character" (a character who was not in any way present in the original outline) implies that most characters reused in other episodes cannot be considered as original because they were mentioned in the original outline. 
La rémunération et les droits d'auteur ne donnent ainsi pas suffisamment de poids aux scénaristes dans leurs négociations en matière de statut et de reconnaissance. En conséquence, les crédits portés au générique sont la seule reconnaissance publique dont ils et elles bénéficient (à travers la stricte mention written by, suivie de leur nom). L'attribution des crédits est le résultat d'un arrangement social entre le showrunner et les scénaristes, déguisé en discours sur l'équité (Hughes 1984 : 216-326). R. T. Davies défend ainsi une volonté d'être " juste » envers les scénaristes, tout en se sentant «pris au piège » (Davies \& Cook $2010: 176-177$ ) par une politique qui donne du crédit (non mérité) aux scénaristes. $R$. Shearman a également souligné la contradiction de se voir attribuer des choix créatifs jugés mauvais par l'audience alors qu'il n'en était pas l'auteur stricto sensu (car ces éléments faisaient partie de l'intrigue originale ou de scènes qu'il a dû modifier). Le malaise des deux parties met en évidence la contradiction qui existe entre la définition conventionnelle de l'auteurité et la réalité du scénario comme produit d'un collectif. Comme pour une œuvre de Rembrandt, "l'authentification » se révèle souvent impossible (Alpers 1991). Néanmoins l'attribution des crédits dépend aussi des pratiques locales de l'industrie télévisée de manière générale. Les scénaristes, au Royaume-Uni, sont reconnu·e.s individuellement en tant qu'auteur.e.s, par opposition au modèle de la writers' room (littéralement « la salle des scénaristes ») dominant aux États-Unis. Cette situation est due à la proximité de la télévision britannique avec le théâtre, ainsi qu'à l'importance des mini-séries (souvent des adaptations de roman en six épisodes). Les scénaristes s'attendent donc à bénéficier de l'accréditation complète et d'un certain degré d'autonomie. Leur recrutement implique d'ailleurs leur présence dans les crédits au générique, mais aussi leur visibilité médiatique (interviews dans la presse, présence sur les supports promotionnels, etc., - sans que cela ne soit une source supplémentaire de revenu). Ces éléments ont permis de recruter
Thus, pay and rights regulations do not allow for enough leverage to shape writers' recognition policies. Consequently, credits and therefore public recognition become the central mechanism through which writers are rewarded. The main credit policy was "full credits," that is through the title "written by" followed by the writer's name alone in the titles. It resulted from an arrangement between the showrunner and writers, hidden behind a discourse revolving around fairness (Hughes 1984: 316-326). R. T. Davies indeed claims wanting to be "fair" to writers, while feeling "trapped" (Davies \& Cook 2010: 176-177) by a policy that gives (unfair) credit to writers for pieces of scripts written by him (as for the episode "Human nature," Davies \& Cook 2010: 130). R. Shearman also noted the unfairness of being blamed for creative choices he had not made (be it the original outline or specific scenes). The uneasiness of both sides reveals the contradiction between the conventional definition of authorship and the reality of scripts being the product of a collective, just as "authenticating" Rembrandt paintings is almost impossible (Alpers 1988). Nevertheless, credit policy is also shaped relatively to local practices in the industry. Writers in British television are recognized as individual authors, in contrast to the writers' room, which is hegemonic in the US. It is due to the original proximity of British television with theatre, as well as the importance of serials (6-episode novel adaptations). Full credits (and a degree of professional autonomy) is thus expected by writers. Aiming at recruiting "good" writers, who can afford to refuse a proposal to work on the show, thus implies recognizing their work through credits as well as through media visibility (interviews in the press, presence on promotional pictures and videos, etc., - without these activities being an extra source of revenue). Romantic comedy writer Richard Curtis, bestselling author Neil Gailman or playwright Mike Bartlett are a few examples of the success of this strategy. 
des scénaristes reconnus, comme Richard Curtis, scénariste de comédies romantiques de renom, Neil Gaiman, auteur à succès ou encore le dramaturge Mike Bartlett.

Une co-accréditation avec le showrunner (mention written by... and... au générique) a aussi été envisagée, comme une manière de prévenir le ou la scénariste de la réécriture potentiellement massive à venir : c'était la stratégie de R. T. Davies pour «Waters of Mars 》 (Davies \& Cook 2010 : 258). Cependant, une telle configuration implique aux yeux des scénaristes une plus grande coopération que ce qui est en général le cas. C'est ainsi que P. Ford n'a pas apprécié devoir partager le générique pour son second épisode, «Into the Dalek» («Dans le ventre du Dalek»), d'autant que cela n'avait pas été clairement précisé au moment de la commande. Après une tentative de généralisation pour la saison 8 , le principe de co-accréditation a été abandonné.

Ainsi la notion d'auteurité créative, considérée comme simple possibilité de faire des choix créatifs, existe sous de nombreuses formes et concerne plusieurs personnes dans le processus d'écriture. Considérée comme contrôle créatif total sur l'œuvre globale, en revanche, elle ne peut être attribuée à quiconque. Une représentation plus souple de cette notion est donc nécessaire. Toutefois, la reconnaissance individuelle structure l'industrie télévisuelle : les crédits portés au générique sont donc négociés à chaque fois, créant des conflits latents dans l'organisation du travail. Bien que la notion d'auteur, et plus largement de « talent », soit une construction sociale, cela ne l'empêche pas de structurer le processus de production et particulièrement les modes de management des travailleurs.
Still, co-credits were envisaged as a way to let the writers know they would be rewritten extensively, which was R. T. Davies' strategy on "Waters of Mars" (Davies \& Cook 2010: 258). However, it implied a closer cooperation between showrunner and writer than usual on the show, so P. Ford did not appreciate having to share his credits for "Into the Dalek," when it had not been established as such when he was commissioned. Attempted on series 8 , this policy was then dropped.

To sum up, creative authorship, if understood as the power to make creative choices, comes in many forms in television writing; but if understood as total creative control, such cannot be attributed. Yet, the industry's configurations require individual recognition: credits are thus negotiated, creating rampant conflicts inside the organization. Even though the concept of "author" and more broadly of "talent" is a social construct, it does not prevent it from structuring the production process, and particularly management, through and through. 


\section{Getting it right (« faire bien les choses») : obtenir des contenus de qualité passe-t-il par la concentration de l'auteurité et par la plus grande autonomie de quelques-}

uns ?

\subsection{Considérer les travailleur·euse-s comme des talents} conditions et impact

Tout d'abord, l'organisation globale du marché du travail dans l'industrie télévisée amène à une individualisation poussée des carrières, qui sont concues comme des prototypes (Pasquier 1999). Ceci a été renforcé dans l'industrie télévisée britannique par la précarisation, dès les années 1980, à travers laquelle le freelance a remplacé le salariat comme statut d'emploi dominant (Tunstall 1993). Les conditions d'emploi permettent ainsi à des individus de détenir leur propre capital réputationnel (Schotté 2012). Ainsi, dans les entretiens, les enquêté e.s désignent les personnes par leur nom de famille (et même parfois par leur seul prénom) sans mentionner leur fonction, comme si leur identification allait de soi. Par exemple, en retraçant les étapes de sa carrière, $\mathrm{N}$. Wilson mentionne par son seul nom son ancienne supérieure, Linda Laplant (productrice connue dans la télévision britannique). Cette tendance mène à une telle individualisation des travailleur.euse.s que M. Young considère R. T. Davies comme une «marque ». Avec l'hétérogénéisation des carrières, le «talent » a été mis en avant comme valeur fondamentale de l'industrie (Tunstall 1993). Les conditions de travail assez solitaires, particulièrement en freelance, et plusieurs récits personnels renforcent cette individualisation. En conséquence, il existe un certain «mysticisme » autour de l'écriture (et donc, en partie, de l'auteurité) car, effectuée dans l'intimité d'un bureau, elle est très rarement observée (Davies \& Cook 2010 611). Dans les entretiens, cela est verbalisé par l'utilisation de l'expression going away and [doing a task] (« s'en aller de son

\section{3. "Getting It Right": Is Aiming at Quality Giving More Authorship and Autonomy to Few "Talents"?}

\subsection{A Highly Individualized Management: Implicit Talent Ideology and Its Impact on Management}

First, the labour market's structure reinforces the individualisation of careers, which are seen as prototypes (Pasquier 1999). It was strengthened in British television by the casualisation process of the 1980s (Tunstall 1993), which saw freelance becomes the standard form of employment. Employment conditions thus allow for reputation to be held by individuals (Schotte 2012). The use of individuals' names (or first names) instead of their position is thus common in conversations, as if they were self-explanatory. For example, N. Wilson, when remembering her career path, mentioned her former bosses by name, e.g. well-known producer Linda Laplant. This leads to a personalization of workers, to the point where executive M. Young referred to R. T. Davies as a "brand." "Talent" was put forward as a central value (Tunstall 1993) at the same time as careers became more heterogeneous. Solitary working conditions, particularly as freelancers, and individual narratives strengthen individualization, in turn creating a "mystique" around writing, an activity that is rarely witnessed (Davies \& Cook 2010: 611). In interviews, this situation is illustrated by the use of the expression "going away and [doing a task]" to describe one's work (used five times by R. Shearman, six by P. Ford, three by $D$. Ritchie and once by M. Young). In fact, the only moments when the writer is physically co-present alongside all other members of the creative team occur during a small number of meetings. As most writers do not live close to the studio nor do the showrunners, they stay in contact with the production team through other means of communications, such as e-mail. 
côté et [aller faire quelque chose] ») pour décrire certaines étapes du travail (expression utilisée cinq fois par R. Shearman, six par P. Ford, trois par D. Ritchie et une fois par M. Young). En effet, le ou la scénariste n'est physiquement en présence d'autres membres de l'équipe créative que lors de quelques réunions. Ainsi, les scénaristes ou les showrunners ne vivant pas à proximité du studio, ils et elles restent en contact avec la production à travers divers moyens de communication, notamment par mail.

Encouragée par cette individualisation, la notion de «talent», de capacités propres et uniques aux individus à l'origine de la qualité de leur travail, était présente comme croyance implicite dans tous les entretiens, bien qu'un seul enquêté ait explicitement utilisé le terme pour décrire les créateur.rice.s. Un vocabulaire particulier distinguant les capacités des individus est mobilisé : genius (« génie » ou « ingénieux ») est répété cinq fois par P. Ford, brilliant (« génial ») est utilisé à maintes reprises par R. T. Davies. De plus, le modèle du showrunner est conçu comme « un individu jouant le rôle de leader d'un projet ", laissant son " empreinte " sur la série, ce qui est supposé amener distinction et prestige (Higueras, Gomez-Pérez, Alberich-Pascual 2018 : 102). En effet, si un « talent » est unique, l'exploiter signifie le laisser infiltrer un maximum la production, et donc donner l'auteurité la plus grande possible à la personne qui le détient.

Cette situation n'est finalement pas si surprenante, puisque l'idéologie du talent trouve son origine dans les arts, mais cela montre à quel point elle imprègne le champ culturel dans son ensemble, en brouillant ses frontières (Duval 2006), puisque l'industrie télévisée se situe dans son pôle économique. Néanmoins, il faut rappeler que le talent apparaît comme inégalement distribué, notamment en fonction du genre, puisque les femmes ne représentent dans Doctor Who que $14 \%$ des scénaristes (une réalité à l'échelle de
Building on the individualization of workers, the concept of "talent," as inner abilities uniquely linked to individuals at the heart of their production, was implicitly present throughout this research, one interviewee using it explicitly. First, it was notably through the use of topical vocabulary singling out performances: "genius" (used five times by P. Ford) or the word "brilliant," used numerous times by R. T. Davies. Lastly, the showrunner model, giving a great amount of authorship to an individual, requires a belief in individual specificities as it is based "on an individual serving as the project's leading management," leaving their "stamp" on the show, which is deemed to bring distinction and prestige (Higueras, Gomez-Pérez, Alberich-Pascual 2018:102). Indeed, if one's "talent" is unique, using it means letting it spread to the entire production and thus giving maximal authorship to its owner.

All in all, this situation is not surprising, since talent ideology stems from the arts, but it shows its magnitude, as well as the blurring of boundaries in the cultural field (Duval 2006), since television industries are tied to its commercial side. Yet, talent appears to be unevenly distributed, especially considering gender, with women representing only $14 \%$ of writers (an inequality permeating the whole industry, but worsened here by typecasting- Bielby \& Bielby 1996), talent ideology can be exposed as a justification of social 
l'industrie, mais accentuée ici par le «catalogage » - typecasting des scénaristes, Bielby \& Bielby 1996). Cela montre comment l'idéologie du talent, qui recouvre en partie l'expérience, l'ancienneté, l'éducation ou encore le genre, justifie en partie des inégalités sociales. Cette représentation du monde transforme ensuite l'organisation du travail, à commencer par le recrutement.

Tout d'abord, l'ambition de recruter des scénaristes « talentueux » amène parfois à considérer de recruter des écrivain.e.s avec aucune ou peu d'expérience dans l'industrie télévisuelle, ce qui peut engendrer des coûts et des retards. Par exemple, R. Shearman, qui est plus habitué au théâtre, a écrit dix versions de son scénario, alors que l'on tourne en général plus autour de trois ou quatre versions, tandis que Richard Curtis, venant du cinéma, a imposé sa femme comme script editor. En outre, le management des talents implique en premier lieu la protection de ces derniers et recouvre non le fait de trouver une solution aux problèmes, mais celui de permettre aux « talents » de la trouver, comme le décrit $\mathrm{D}$. Ritchie :

" Je ne suis pas là pour dire : "Tu devrais écrire cela." C'est un dialogue. [...] Tu veux que ce soit EUX, que tu emploies pour cette raison, en raison de leur talent, que [...] eux trouvent une solution meilleure que ce que tu n'aurais jamais pu trouver. »

Commele notent HesmondhalghetBaker (2011:84), le management des créateur.rice. $s$ est conçu comme moins directif, car la créativité serait réticente aux ordres. D. Ritchie décrit ainsi son travail de manager : «Tu dois vraiment [...] tirer les ficelles pour identifier le nœud du problème. » Être capable de stimuler la créativité et mettre les détenteurs de l'auteurité dans de bonnes conditions devient bien plus important que représenter une quelconque forme d'autorité. Valoriser les talents implique également une forme de soin, particulièrement pour les productrices. N. Wilson décrit ainsi inequalities. This ideology then informs the organization of labour particularly management and recruiting.

First, the will to recruit "talented" writers leads to considering recognized writers with little to no experience in television, which can create costs and delays. For example, R. Shearman, who is more used to theatre, wrote ten drafts of his episode, when the norm is around three or four drafts, while Richard Curtis imposed his wife as script editor. Secondly, talent management implies protecting talents, while considering that, as a manager, one cannot find the answer, but only help the talent find it. As D. Ritchie puts it:

"I'm not here to say, 'I think you should write this'. This is a dialog. [...] you want THEM, which is why you employ them, because of their talent, to $[\ldots]$ come up with a solution better than you could have ever, ever found."

As Hesmondhalgh and Baker noted (2011: 84), creative management is conceived as less directive, because creativity is reluctant to follow orders. D. Ritchie thus describes his job as manager : "You really have to [...] pull that down to get to the knot of the problem." Triggering creativity trumps representing authority. Valuing talent also implies a form of care, especially for female producers. N. Wilson depicts her job as producer as "holding the director's hand," providing moral support. It also means being 
son travail comme « tenir le réalisateur par la main », en fournissant un soutien moral. Cela signifie être joignable en permanence et effectuer les ajustements nécessaires pour réaliser les idées de son « talent » (par exemple trouver des financements pour un épisode à la dernière minute, Davies \& Cook 2010 : 373), ce qui

n'est pas sans conséquences sur le processus de production.

\subsection{Getting away with it (« s'en tirer sans une égratignure ») :} entraver le processus industriel de production au nom du

talent

Décrivant son métier, D. Ritchie évoque avec enthousiasme la spécificité du travail avec les «talents »: «C'est un équilibre précaire entre s'assurer que les personnes [talentueuses] savent ce qu'elles font mais qu'elles ont également la marge de manœuvre nécessaire pour qu'elles puissent donner leur maximum. ”

Les « talents » peuvent ainsi entraver le processus de production au nom de l'ambition créative, qui est incarnée par l'expression « getting it right» (« faire les choses bien »). La représentation des scénaristes comme «talents » et détenteurs légitimes de l'auteurité, avec leurs particularités, leur permet de "s'en tirer sans une égratignure » quasiment en toutes circonstances (Davies \& Cook 2010 : 231), même si cela signifie que leurs conditions de travail peuvent parfois être assez extrêmes (comme l'illustrent les nuits blanches de R. T. Davies)

Concrètement, être reconnu.e.s comme talents fournit aux scénaristes la légitimité nécessaire pour avoir plus d'auteurité (ou pour l'exiger), particulièrement pour le pitch et la réécriture. Le pitch est un résumé vendeur d'une ou plusieurs idées. Pour les scénaristes, il se concentre sur l'intrigue de l'épisode, toutes les contraintes de production étant transformées en éléments de reachable at all times and making arrangements to carry out the "talented" persons' ideas (e.g. rising money to finance episodes at the last minute- Davies \& Cook 2010: 373). However, more than management, the belief in "talent" impacts the production process, disrupting it to let talents' creativity express itself.

\section{2. "Getting Away with It": Disrupting the Industrial Production Process in the Name of Talent}

In describing his job, D. Ritchie enthusiastically referred to the specificity of working with "talents" as: "It's really walking a fine line of making sure that [these talented] people know what they're doing but know they have freedom to make the most of it."

"Talents" can thus disrupt the industrial process in the name of ambition, which is illustrated in the industry by the phrase "get[ting] it right." The representation of writers as "talents," which makes them the legitimate holders of authorship, with their idiosyncrasies directly linked to their creativity, allows them "to get away with murder" (Davies \& Cook 2010: 231). Yet it also means that working conditions can get quite extreme (as illustrated by R. T. Davies' allnighters).

In concrete terms, being recognized as a talent gives a writer the legitimacy to be given (or to claim) more authorship, especially for pitching and getting rewritten. Pitching refers to a selling summary of an idea. For writers, pitching focuses on the plot of the episode, with all production criteria being translated in narrative terms (Mille 2013:172). Asking about pitching is topical in media interviews, 
narration (Mille 2013 : 172). Les questions à ce sujet sont classiques lors des interviews médiatiques, ce qui nous a permis d'en avoir un aperçu. R. Shearman a par exemple reçu un pitch sous la forme d'un paragraphe à partir duquel travailler. La légitimité, c'est-àdire le fait d'être reconnu'e comme « talent », donne aussi le droit de proposer un pitch : il s'agit alors d'un transfert d'agentivité et d'auteurité, impliquant une prise de risque, entre le showrunner et le ou la scénariste. Ainsi M. Bartlett, dramaturge et scénariste réputé, a-t-il eu le droit de proposer un pitch (voir vidéo ci-dessous). Certain-e.s scénaristes peuvent même sauter l'étape du pitch et passer directement à la rédaction : ce fut le cas de $\mathrm{S}$. Moffat pour la saison 4, ce qui créa par la suite des problèmes en raison de ressemblances avec un autre épisode (Davies \& Cook 2010 : 246-247). II en est de même pour la réécriture : les scénaristes réputéee-s peuvent éviter de voir leur scénario réécrit par le showrunner (S. Moffat, M. Graham, C. Chibnall et S. Greenhorn pour la saison 4, Davies \& Cook $2010: 150)$, tandis que le scénario proposé par des scénaristes moins reconnu·e.s, comme J. Moran, peut être réécrit de façon extensive.

\section{https://www.youtube.com/watch?v=SPk2d7LNr5k}

Pourtant, la flexibilité et l'auteurité que peuvent obtenir certain·e·s scénaristes reste limitée comparée à celles du showrunner qui peut décider de l'existence même d'un épisode. Cette différence peut affecter même les scénaristes les plus reconnu·e·s, par exemple Mark Gatiss dans la saison 4 (Davies \& Cook 2010 : 96-97, 108). L'épisode 8 de la saison 4 constitue un exemple particulièrement intéressant. Un mois avant le début du tournage, R. T. Davies voulut et put faire un tout nouvel épisode (qui était cependant peu coûteux car il s'agissait d'un huis-clos dans une navette spatiale), écrivant le scénario dans ce court délai. Les showrunners peuvent ainsi obtenir des changements majeurs dans le calendrier de giving us insight. R. Shearman was given only a one-paragraph pitch to work on, for instance. Legitimacy can earn someone the right to pitch, which is a transfer of agency and authorship from showrunner to writer and means taking a risk. For instance, Mike Bartlett, whose theatre and television record provided for his reputation, had to pitch (see video below). Some writers even dodge the pitching step altogether, directly writing a draft: it was the case for S. Moffat on series 4, creating trouble due to plot resemblance with another episode (Davies \& Cook 2010: 246-247). Rewriting worked in the same way: established writers avoided being rewritten (S. Moffat, M. Graham, C. Chibnall and S. Greenhorn on series 4, Davies \& Cook 2010: 150), while less recognized writers, such as J. Moran, were heavily rewritten.

\section{https://www.youtube.com/watch?v=SPk2d7LNr5k}

Moreover, the flexibility and the authorship offered to writers is limited compared to that of the showrunner. His authorship affects the existence of episodes themselves. It can happen with the most established writers on the show, such as writer Mark Gatiss in series 4 (Davies \& Cook 2010: 96-97, 108). The 8th episode of series 4 is an interesting example. A month before shooting began, R. T. Davies decided to write and entirely different episode (though cheaper, being a "behind closed doors" episode), writing the script in the meantime. Showrunners can ask for drastic changes in overall scheduling: upon arrival, showrunners S. Moffat and then Chibnall asked for a "gap year" in order to put their production team together. 
production : à leur arrivée, S. Moffat et par la suite C. Chibnall (showrunner actuel) demandèrent une « année de césure » afin de pouvoir constituer leur équipe de production. Le showrunner peut également sauter la plupart des étapes du processus de production, et particulièrement d'écriture, car il a tendance à accumuler les retards en raison de ses nombreuses responsabilités. Par exemple, R. T. Davies, pour la saison 4, fournit la première version de plusieurs scénarios le jour du tone meeting, ou même après, de sorte que le tournage dut parfois être repoussé, avec d'importants coûts supplémentaires (pour l'épisode de Noël 2008 notamment). II s'agissait d'une situation banale lorsque S. Moffat était en poste, ses nombreux retards compliquant le processus d'écriture vis-à-vis des scénaristes, comme P. Ford.

\section{Conclusion}

Cet article montre comment, bien que collectif par essence, le processus d'écriture de Doctor Who peut être appréhendé, non pas seulement à travers la notion d'auteur, mais à travers celle d'auteurité, qui permet de proposer une vision de la création plus proche de la réalité. Pourtant, dans les industries créatives, la reconnaissance, qui passe par la présence des scénaristes au générique, reste individuelle et le résultat de rapports de force. Enfin, la croyance en l'existence du « talent » et l'importance de l'auteurité qui lui est associée dans ces industries ont des conséquences sur les perceptions et les comportements des acteurs. Les inégalités de traitement qui en découlent influencent ainsi directement l'organisation du travail et le processus de production dans son ensemble, qui apparaît relativement " désordonné " au quotidien, bien loin du processus standardisé supposé être en place. Cela illustre comment, même dans les secteurs les plus industrialisés de la production culturelle, la croyance en l'art et en l'artiste est valorisée et peut l'emporter, dans une certaine mesure, sur les contraintes économiques et industrielles.
The showrunner can also bypass most of the writing process, as his many responsibilities make him prone to delays. $R$. T. Davies delivered several first drafts on the day of the tone meeting or even later, so that the shooting schedule had to be pushed back, with extra costs (for instance the 2008 Christmas episode). It was still happening under S. Moffat, as P. Ford reported writing his episode before $\mathrm{S}$. Moffat had written the first episode, which complicated the writing process.

\section{Conclusion}

To conclude, this article attempted to show that, despite being fundamentally collective, the writing process of Doctor Who could still be apprehended in terms of authorship, providing a more comprehensive definition of the term, refusing the definition of authorship as individual. Furthermore, in the industry, creative workers are represented as talented individuals, so that credits are the results of power relationships in the workplace. Finally, the belief in "talents" and in the importance of their authorship in the industry has consequences on the industrial process of production, giving more power to those identified as "talents," disrupting traditional management methods and the production process as a whole. This made the day-to-day writing process quite erratic, far from the standardized process that theoretically prevails. The consequences of this belief show how, even industrious parts of cultural production, the belief in art and in the artist is valued and can overcome, to a certain degree, industrial and economic constraints.

École normale supérieure de Paris Saclay - Département des sciences sociales (Sociens) 


\section{Références bibliographiques}

AlPERS Svetlana (1991) [1988]. L’Atelier de Rembrandt. La liberté, la peinture et l'argent. Paris, Gallimard.

BAnks Miranda J. (2009). « Gender Below-The-Lines. Defining Feminist Production Studies ». In MAYER Vicki, BANKs Miranda J., CALDWELL John T. (dir.), Production Studies. Cultural Studies of Media Industries. New York, Routledge : 87-98.

BECKER Howard S. (1974). « Art as Collective Action ». American Sociological Review, 39(6) : 767-776.

Bielby Denise D. \& Bielby William T. (1996). « Women and Men in Film : Gender Inequality among Writers in a Culture Industry ». Gender \& Society, 10(3) : 248-270.

BorN Georgina (2004). Uncertain Vision. Birt, Dyke and the Reinvention of the $B B C$. Londres, Secker \& Warburg.

Bourdieu Pierre (1992). Les Règles de l'art. Genèse et structure du champ littéraire. Paris, Seuil.

Burns Gary C. \& ThOMPson Robert (1990). Making Television. Authorship and the Production Process. New York, Praeger.

BUTLER David (2007) Time and Relative Dissertations in Space. Critical Perspectives on Doctor Who. Manchester, Manchester University Press.

CORNEA Christina (2009). «Showrunning the Doctor Who Franchise. A Response to Denise Mann ». In Vicki MAYER, Miranda J. BANKS, John T. CaldWell (dir.), Production Studies. Cultural Studies of Media Industries. New York, Routledge : 115-121.

Davies Elisabeth \& McKenZIE Pamela J. (2004). « Preparing for Opening Night : Temporal Boundary Objects in Textually-Mediated Professional Practice ». Information Research : An International Electronic Journal, 10(1)

\section{References}

AlPERS Svetlana (1988). Rembrandt's Enterprise. The Studio and the Market. Chicago, University of Chicago Press.

BANKS Miranda J. (2009). "Gender Below-The-Lines. Defining Feminist Production Studies." In Vicki MaYER, Miranda J. BANKS, John T. CALDWELL (eds.), Production Studies. Cultural Studies of Media Industries. New York, Routledge: 87-98.

BeCKER Howard S. (1974). "Art as Collective Action." American Sociological Review, 39(6): 767-776.

Bielby Denise D. \& Bielby William T. (1996). "Women and Men in Film: Gender Inequality among Writers in a Culture Industry." Gender \& Society, 10(3): 248-270.

BorN Georgina (2004). Uncertain Vision. Birt, Dyke and the Reinvention of the BBC. London, Secker \& Warburg.

BOURDIEU Pierre (1996) [1992]. The Rules of Art. Genesis and Structure of the Literary Field. Translated by Susan Emanuel. Palo Alto, Stanford University Press.

Burns Gary C. \& ThOMPson Robert (1990). Making Television. Authorship and the Production Process. New York, Praeger.

ButLer David (2007) Time and Relative Dissertations in Space. Critical Perspectives on Doctor Who. Manchester, Manchester University Press.

CORNEA Christina (2009). "Showrunning the Doctor Who Franchise. A Response to Denise Mann." In MAYER Vicki, BANKS Miranda J., CALDWELL John T. (eds.), Production Studies. Cultural Studies of Media Industries. New York, Routledge: 115-121.

Davies Elisabeth \& McKenzIE Pamela J. (2004). "Preparing for Opening Night: Temporal Boundary Objects in Textually-Mediated Professional Practice." Information Research: An International Electronic Journal, 10(1). 
Davies Russell T. \& Cook Benjamin (2010). Doctor Who. The Writer's Tale. Londres, BBC Books.

DuVAL Julien (2006). « L'art du réalisme. Le champ du cinéma français au début des années 2000 ». Actes de la recherche en sciences sociales, 161-162 : 96-115.

Hesmondhalgh David \& Baker Sarah (2011). Creative Labour. Media Work in Three Cultural Industries. Londres/New York, Routledge.

Higueras-Ruiz Maria-José, Gomez-Pérez Francisco Javier, AlberichPASCUAL Jordi (2018). " Historical Review and Contemporary Characterization of Showrunner as Professional Profil in TV Series Production : Traits, Skills, Competences, and Style ». Communication \& Society, $31:$ : 91-106.

HUGHES Everett Cherrington (1984) [1971]. The Sociological Eye : Selected Papers. New Brunswick, Transaction Books.

LAURENS Sylvain (2007). " "Pourquoi" et "comment" poser les questions qui fâchent ? ". Genèses, 69 : 112-127.

Mengen Pierre Michel (2009). Le Travail créateur. S'accomplir dans l'incertain. Paris, Le Seuil.

MiLLE Muriel (2016). « Le processus collectif de création d'un feuilleton télévisé ». Sociétés contemporaines, $101:$ 91-114.

MILLE Muriel (2013). Produire de la fiction à la chaîne : sociologie du travail de fabrication d'un feuilleton télévisé. Thèse de doctorat en sociologie. Paris, EHESS.

PAsquier Dominique (1999). Les Scénaristes et la télévision. Approche sociologique. Paris, Nathan Université.

Robinson Timothy Mark (2010). «Agency, Action, and Re-Action : The Black Female Presence in Doctor Who ». In Christopher J. HANSEN, Ruminations, Peregrinations, and Regenerations: A Critical Approach to Doctor Who (nouvelle édition). Newcastle Upton Tyne, Cambridge Scholars Publishing
DAVIES Russell T. \& Cook Benjamin (2010). Doctor Who. The Writer's Tale. London, BBC Books.

DUVAL Julien (2006). "L'art du réalisme. Le champ du cinéma français au début des années 2000." Actes de la recherche en sciences sociales, 161-162: 96-115.

Hesmondhalgh David \& Baker Sarah (2011). Creative Labour. Media Work in Three Cultural Industries. London/New York, Routledge.

Higueras-Ruiz Maria-José, Gomez-Pérez Francisco Javier, AlberichPAscual Jordi (2018). "Historical Review and Contemporary Characterization of Showrunner as Professional Profil in TV Series Production: Traits, Skills, Competences, and Style." Communication \& Society, 31: 91-106.

HUGHES Everett Cherrington (1984) [1971]. The Sociological Eye: Selected Papers. New Brunswick, Transaction Books.

LAURENS Sylvain (2007). “'Pourquoi' et 'comment' poser les questions qui fâchent?” Genèses, 69: 112-127.

Menger Pierre-Michel (2016). Difference, Competition and Disproportion. The Sociology of Creative Work. Translated by Liz Libbrecht. Paris, Collège de France.

Mille Muriel (2016). "Le processus collectif de création d'un feuilleton télévisé." Sociétés contemporaines, 101: 91-114.

Mille Muriel (2013). Produire de la fiction à la chaîne: sociologie du travail de fabrication d'un feuilleton télévisé. PhD. Thesis, Sociology. Paris, EHESS.

PAsquier Dominique (1999). Les Scénaristes et la télévision. Approche sociologique. Paris, Nathan Université.

RoBinson Timothy Mark (2010). "Agency, Action, and Re-Action: The Black Female Presence in Doctor Who." In Christopher J. HANSEN, Ruminations, Peregrinations, and Regenerations: A Critical Approach to Doctor Who (new edition). Newcastle Upton Tyne, Cambridge Scholars Publishing. 
SchotTé Manuel (2012). La Construction du talent. Sociologie de la domination des coureurs marocains. Paris, Liber.

Tulloch John \& Alvarado Manuel (1984). Doctor Who. The Unfolding Text. Londres, Macmillan.

Tulloch John \& Jenkins Henry (1995). Science Fiction Audiences: Watching Doctor Who and Star Trek. New York, Routledge.

TUNSTALL Jeremy (1993). Television Producers. New York, Routledge.
Schotté Manuel (2012). La Construction du talent. Sociologie de la domination des coureurs marocains. Paris, Liber.

Tulloch John \& Alvarado Manuel (1984). Doctor Who. The Unfolding Text. London, Macmillan.

TUlLoch John \& JenkINS Henry (1995). Science Fiction Audiences: Watching Doctor Who and Star Trek. New York, Routledge.

TUNSTALL Jeremy (1993). Television Producers. New York, Routledge. 